\title{
Spatio-Temporal Differences in Nitrogen Reduction Rates under Biotic and Abiotic Processes in River Water of the Taihu Basin, China
}

\author{
Jiaxun Guo ${ }^{1}$, Lachun Wang ${ }^{1}$, Xiya Guo ${ }^{2}$, Gengmao Zhao ${ }^{3}$, Jiancai Deng ${ }^{2, *}$ and Chunfen Zeng ${ }^{1}$ \\ 1 School of Geographic and Oceanographic Sciences, Nanjing University, Nanjing 210023, China; \\ DG1727009@smail.nju.edu.cn (J.G.); wang6312@nju.edu.cn (L.W.); zengchunfen@hotmail.com (C.Z.) \\ 2 Nanjing Institute of Geography and Limnology, Chinese Academy of Sciences, Nanjing 210008, China; \\ Everlasting_west@163.com \\ 3 College of Resources and Environmental Sciences, Nanjing Agricultural University, Nanjing 210095, China; \\ seawater@njau.edu.cn \\ * Correspondence: jcdeng@niglas.ac.cn; Tel.: +86-025-86882181
}

Received: 15 October 2018; Accepted: 14 November 2018; Published: 16 November 2018

\begin{abstract}
Understanding spatio-temporal differences in nitrogen $(\mathrm{N})$ transformation, transport and reduction rates in water bodies is critical to achieve effective mitigation of river eutrophication. We performed culture experiments in six rivers in the Taihu Basin using a custom made in-situ experimental apparatus. We investigated spatio-temporal differences in reduce processes and rates of different $\mathrm{N}$ forms and assessed the contribution of biological processes to dissolved inorganic N (DIN) reduce. Results showed that biological processes played a major role in $\mathrm{N}$ reduction in summer, while non-microbial processes were dominant in winter. We observed significant spatial and temporal differences in the studied mechanisms, with reduction rates of different $\mathrm{N}$ compounds being significantly higher in summer and autumn than spring and winter. Reduction rates ranged from $105.4 \pm 25.3$ to $1458.8 \pm 98.4 \mathrm{mg} \cdot\left(\mathrm{m}^{3} \cdot \mathrm{d}\right)^{-1}$ for total $\mathrm{N}, 33.1 \pm 12.3$ to $440.9 \pm 33.1 \mathrm{mg} \cdot\left(\mathrm{m}^{3} \cdot \mathrm{d}\right)^{-1}$ for ammonium, $56.3 \pm 22.7$ to $332.1 \pm 61.9 \mathrm{mg} \cdot\left(\mathrm{m}^{3} \cdot \mathrm{d}\right)^{-1}$ for nitrate and $0.4 \pm 0.3$ to $31.8 \pm 9.0 \mathrm{mg} \cdot\left(\mathrm{m}^{3} \cdot \mathrm{d}\right)^{-1}$ for nitrite across four seasons. Mean DIN reduction rates with and without microbial activity were $96.0 \pm 46.4 \mathrm{mg} \cdot\left(\mathrm{m}^{3} \cdot \mathrm{d}\right)^{-1}$ and $288.1 \pm 67.8 \mathrm{mg} \cdot\left(\mathrm{m}^{3} \cdot \mathrm{d}\right)^{-1}$, respectively, with microbial activity rates accounting for $29.7 \%$ of the DIN load and $2.2 \%$ of the $\mathrm{N}$ load. Results of correlation and principal component analysis showed that the main factors influencing $\mathrm{N}$ processing were the concentrations of different $\mathrm{N}$ forms and multiple environmental factors in spring, $\mathrm{N}$ concentrations, $\mathrm{DO}$ and $\mathrm{pH}$ in summer, $\mathrm{N}$ concentrations and water velocity in autumn and $\mathrm{N}$ concentrations in winter.
\end{abstract}

Keywords: nitrogen reduce; spatio-temporal differences; biotic and abiotic; in-situ; Taihu Basin

\section{Introduction}

Nitrogen $(\mathrm{N})$ is an essential nutrient element for all organisms, but excessive inputs of bioavailable $\mathrm{N}$ from anthropogenic activities have severely impacted aquatic ecosystems [1-3]. Excess amounts of $\mathrm{N}$ can cause eutrophication and deterioration of ecosystems and water quality. For example, two thirds of the coastal rivers and bays in the United States are moderately to severely degraded due to $\mathrm{N}$ pollution (U.S. Environmental Protection Agency, 2001), and more than $85 \%$ of the lakes and about $82 \%$ of the 532 major rivers in China experienced eutrophication and water quality deterioration due to heavy N pollution [4]. Processes such as organic matter burial in sediment, denitrification, sediment adsorption and plant and microbial uptake can remove $\mathrm{N}$ transported in rivers and streams, thereby reducing the amount of $\mathrm{N}$ exported to lakes and reservoirs [5]. Therefore, reduction of $\mathrm{N}$ pollution 
in surface waters should not only focus on decreasing $\mathrm{N}$ inputs but also on improving $\mathrm{N}$ removal capacity in water bodies [6,7]. Measures commonly adopted to control $\mathrm{N}$ pollution include reducing pollutants from industrial and domestic sources and intercepting waterborne pollutants before they enter rivers. Examples of such measures are the "Zero Pollution" actions in the Lake Taihu region in China $[7,8]$.

When point source pollutants discharged directly into water bodies are controlled effectively, rivers are the main sources of pollutants to lakes and oceans. Aquatic ecosystems naturally possess self-purification capacities. After $\mathrm{N}$ enters aquatic ecosystems, part of it is removed through biological processes (e.g., biodegradation and adsorption) and abiotic processes (e.g., dilution, deposition, volatilization and oxidation [9]. In aquatic ecosystems, bacterial denitrification is considered the primary pathway for permanent $\mathrm{N}$ removal via $\mathrm{N}_{2}$ production, with other processes acting as only temporary $\mathrm{N}$ storage mechanisms [10]. Bacterial denitrification and $\mathrm{N}$ removal rates have been estimated in several rivers and lakes. For example, denitrification rates were $0.25-0.63 \mathrm{mmol} \mathrm{N} \cdot \mathrm{L}^{-1} \cdot \mathrm{d}^{-1}$ in Poyang Lake's suspended sediments, $0-56.4 \mathrm{mg} \mathrm{N} \cdot \mathrm{m}^{-2} \cdot \mathrm{d}^{-1}$ in sediments in the Taihu Basin and $274-2111 \mathrm{mg} \mathrm{N} \cdot \mathrm{m}^{-2} \cdot \mathrm{d}^{-1}$ in the water of a Lake Superior estuary; $\mathrm{N}_{2} \mathrm{O}$ emission rates were 0.04-56.47 $\mathrm{mg} \mathrm{N} \cdot \mathrm{m}^{-2} \cdot \mathrm{d}^{-1}$ in urban rivers and $0.01-80.9 \mathrm{mg} \mathrm{N} \cdot \mathrm{m}^{-2} \cdot \mathrm{d}^{-1}$ in runoff rivers; $\mathrm{N}_{2}$ production rates ranged between 19.08 and $375.44 \mathrm{mg} \mathrm{N}-\mathrm{N} \cdot \mathrm{m}^{-2} \cdot \mathrm{d}^{-1}$ in western Lake Taihu [11-15]. Processes contributing to $\mathrm{N}$ removal in water and sediments are affected by several environmental factors, including water temperature and concentrations of $\mathrm{NO}_{3}{ }^{-}-\mathrm{N}$, dissolved oxygen (DO) and suspended solids [13-16].

Most studies have focused on $\mathrm{N}$ removal rates out of water. Although permanent $\mathrm{N}$ removal is achieved by microbial processes, sedimentation of suspended solids containing $\mathrm{N}$ adsorbed to their surface can also contribute to $\mathrm{N}$ reduce. Previous studies have generally focused on biological mechanisms, while the contribution of other processes to $\mathrm{N}$ reduction rates has not been studied extensively. Furthermore, a large proportion of studies on $\mathrm{N}$ reduction was conducted in the laboratory using simulations that are often unable to accurately capture complex environmental processes. To improve the current understanding of $\mathrm{N}$ reduction rates in natural rivers, we investigated $\mathrm{N}$ reduction rates in six rivers in the Taihu Basin using a custom made in-situ experimental apparatus. In each river, we analyzed the $\mathrm{N}$ concentrations of different treatments in the culture bottles before and after the experiment. Based on the results, we quantified $\mathrm{N}$ reduction rates and evaluated the main processes contributing to $\mathrm{N}$ reduce. Specifically, we assessed the relative contribution of biotic and abiotic processes and explored the effects of different environmental factors on $\mathrm{N}$ reduce processes. Our study is based on two hypotheses, (1) the biochemical activity can significantly reduce $\mathrm{N}$ in natural water within one day, and (2) the device can attain the same environmental conditions found in each river.

\section{Materials and Methods}

\subsection{Site Description}

The Lake Taihu Basin is located in the center of the Yangtze River Delta in southeastern China, one of China's most economically developed regions. The region is characterized by a dense river network and is heavily populated, with a large portion of the population residing along rivers and leading to developed industry and intensive agriculture. The region is dominated by a subtropical monsoon climate, with a rainy season (average amount of rainfall: $750-850 \mathrm{~mm}$ ) occurring from May to September and alternating with a dry season (average rainfall: $250-350 \mathrm{~mm}$ ). Annual mean air temperature varies between $14.9^{\circ} \mathrm{C}$ and $16.2^{\circ} \mathrm{C}$.

We sampled six rivers in the Lake Taihu region (Figure 1) in July 2015 and February, October and December 2016. Sampling months were selected to represent summer, spring, autumn and winter conditions, respectively. Physico-chemical parameters measured at each sampling site in spring, summer, autumn and winter were showed in Table 1. The sampling points were conducted 
in six rivers including the Danjinlicao River (point DC), Beijing-Hangzhou Canal-Jiaxin (point JX), Beijing-Hangzhou Canal-Pingwang (point PW), Nanxi-Xijiu River (point NX), Taige River (point TG), and Taipu River (point TP), which span a diverse range of environmental conditions, functions and geographic features. The main sources of $\mathrm{N}$ pollution to these rivers include industrial wastewater, domestic sewage and agricultural fertilizers from the surrounding areas. Specifically, DC is located in the city of Jintan and is mainly used for shipping, with an average dissolved inorganic $\mathrm{N}$ (DIN) concentrations of $4.29 \mathrm{mg} \cdot \mathrm{L}^{-1}\left(56.68 \%\right.$ as $\mathrm{NH}_{4}{ }^{-}-\mathrm{N}$ and $41.07 \%$ as $\left.\mathrm{NO}_{3}{ }^{-}-\mathrm{N}\right)$. Similarly, JX is also mainly used for shipping and $\mathrm{N}$ pollution to this river derives from sewage and industrial wastewater, resulting in average DIN concentrations of $3.48 \mathrm{mg} \cdot \mathrm{L}^{-1}\left(18.84 \%\right.$ as $\mathrm{NH}_{4}{ }^{-}-\mathrm{N}$ and $77.73 \%$ as $\left.\mathrm{NO}_{3}{ }^{-}-\mathrm{N}\right)$. $\mathrm{NX}$ is located in the city of Yixing, where it supports agricultural activities and shipping, and it exhibits average DIN concentrations of $3.01 \mathrm{mg} \cdot \mathrm{L}^{-1}\left(20.08 \%\right.$ as $\mathrm{NH}_{4}{ }^{-}-\mathrm{N}$ and $76.32 \%$ as $\left.\mathrm{NO}_{3}{ }^{-}-\mathrm{N}\right)$. TG is located in the town of Fenshui, the main $\mathrm{N}$ sources to this river are domestic sewage and industrial wastewater and the average DIN concentrations are $4.01 \mathrm{mg} \cdot \mathrm{L}^{-1}\left(35.20 \%\right.$ as $\mathrm{NH}_{4}{ }^{+}-\mathrm{N}$ and $60.98 \%$ as $\left.\mathrm{NO}_{3}{ }^{-}-\mathrm{N}\right)$. PW and TP are located in the Wujiang District, Suzhou, and their average DIN concentrations amount to $3.44 \mathrm{mg} \cdot \mathrm{L}^{-1}\left(38.73 \%\right.$ as $\mathrm{NH}_{4}{ }^{+}-\mathrm{N}$ and $58.54 \%$ as $\left.\mathrm{NO}_{3}{ }^{-}-\mathrm{N}\right)$ and $1.93 \mathrm{mg} \cdot \mathrm{L}^{-1}\left(21.02 \%\right.$ as $\mathrm{NH}_{4}{ }^{+}-\mathrm{N}$ and $76.59 \%$ as $\mathrm{NO}_{3}{ }^{-}-\mathrm{N}$ ), respectively. Both sampling sites are located in the main channel, but $\mathrm{PW}$ is surrounded by an urban area, while TP is located in a predominantly rural area.

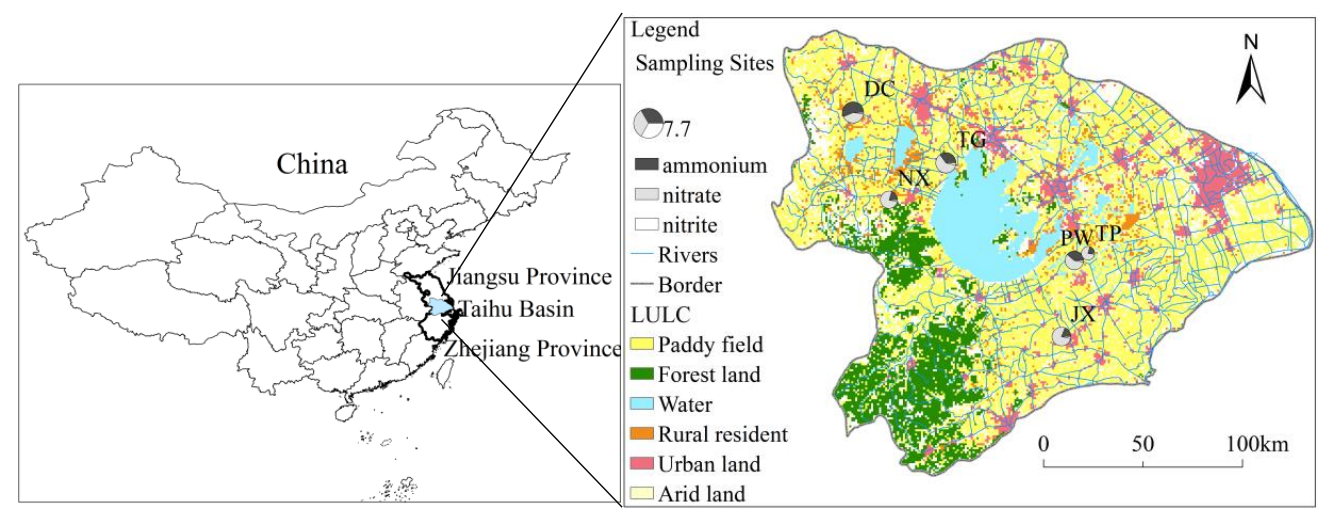

Figure 1. Sampling sites and Land Use/Land Cover (LULC) in the Taihu Basin. The LULC data set was provided by the Data Center for Resources and Environmental Sciences, Chinese Academy of Sciences (RESDC) (http:/ / www.resdc.cn).

Table 1. Physico-chemical parameters measured at each sampling site in spring, summer, autumn and winter.

\begin{tabular}{|c|c|c|c|c|c|c|c|c|c|c|c|c|}
\hline \multirow{2}{*}{ Sites } & \multicolumn{4}{|c|}{$\mathrm{DO}\left(\mathrm{mg} \cdot \mathrm{L}^{-1}\right)$} & \multicolumn{4}{|c|}{$\mathrm{pH}$} & \multicolumn{4}{|c|}{ Velocity $\left(m \cdot s^{-1}\right)$} \\
\hline & Spring & Summer & Autumn & Winter & Spring & Summer & Autumn & Winter & Spring & Summer & Autumn & Winter \\
\hline DC & 7.53 & 2.60 & 4.00 & 6.30 & 7.70 & 7.95 & 8.34 & 7.54 & 0.01 & 0.01 & 0.04 & 0.18 \\
\hline $\mathrm{JX}$ & 8.21 & 2.65 & 4.11 & 5.03 & 7.83 & 7.67 & 8.26 & 7.71 & 0.06 & 0.22 & 0.15 & 0.07 \\
\hline PW & 10.53 & 4.73 & 3.34 & 5.91 & 7.31 & 7.99 & 8.04 & 7.67 & 0.05 & 0.11 & 0.17 & 0.03 \\
\hline NX & 6.70 & 5.72 & 4.53 & 5.71 & 7.66 & 8.23 & 7.77 & 8.25 & 0.35 & 0.08 & 0.13 & 0.05 \\
\hline TG & 7.19 & 8.74 & 4.66 & 6.40 & 8.01 & 8.62 & 7.88 & 7.32 & 0.16 & 0.05 & 0.13 & 0.11 \\
\hline $\mathrm{TP}$ & 10.93 & 5.17 & 3.62 & 6.36 & 7.24 & 8.03 & 7.98 & 7.64 & 0.30 & 0.50 & 0.28 & 0.42 \\
\hline \multirow{2}{*}{ Sites } & \multicolumn{4}{|c|}{ Water Flow $\left(\mathrm{m}^{3} \cdot \mathrm{s}^{-1}\right)$} & \multicolumn{4}{|c|}{$\mathrm{SS}\left(\mathrm{mg} \cdot \mathrm{L}^{-1}\right)$} & \multirow{2}{*}{\multicolumn{2}{|c|}{ River Width (m) }} & \multirow{2}{*}{\multicolumn{2}{|c|}{$\begin{array}{c}\text { River } \\
\text { Cross-Sectional } \\
\text { Area }\left(\mathrm{m}^{2}\right) \\
\end{array}$}} \\
\hline & Spring & Summer & Autumn & Winter & Spring & Summer & Autumn & Winter & & & & \\
\hline $\mathrm{DC}$ & 0.73 & 1.56 & 3.36 & 15.39 & 198.50 & 52.13 & 89.50 & 19.90 & \multicolumn{2}{|c|}{45.96} & \multicolumn{2}{|c|}{109.70} \\
\hline JX & 5.26 & 31.07 & 22.20 & 6.72 & 40.50 & 35.37 & 150.00 & 5.65 & \multicolumn{2}{|c|}{69.13} & \multicolumn{2}{|c|}{141.97} \\
\hline PW & 15.68 & 45.13 & 58.04 & 9.47 & 19.50 & 348.00 & 65.50 & 12.15 & \multicolumn{2}{|c|}{95.35} & \multicolumn{2}{|c|}{393.78} \\
\hline NX & 5.35 & 11.74 & 15.95 & 5.56 & 25.50 & 5.79 & 85.50 & 7.00 & \multicolumn{2}{|c|}{64.06} & \multicolumn{2}{|c|}{145.93} \\
\hline TG & 3.59 & 3.37 & 7.53 & 5.02 & 23.50 & 9.75 & 54.00 & 5.95 & \multicolumn{2}{|c|}{29.60} & \multicolumn{2}{|c|}{67.87} \\
\hline $\mathrm{TP}$ & 239.69 & 464.01 & 250.03 & 331.89 & 25.00 & 22.20 & 52.00 & 6.35 & \multicolumn{2}{|c|}{159.68} & \multicolumn{2}{|c|}{921.654} \\
\hline
\end{tabular}

DO: Dissolved oxygen; SS: Suspended solids. 


\subsection{Experimental Set-Up and Analyses}

We developed an experimental apparatus (Patent No. ZL201520816420.7) to measure in-situ N reduction rates (Figure 2). The device is made of a steel ring with a diameter of $80 \mathrm{~cm}$ and height of $2.5 \mathrm{~cm}$. The steel ring is connected to a central axle by three $2 \mathrm{~cm}$-wide steel plates. Twelve small steel rings with a diameter of ca. $3.5 \mathrm{~cm}$ each was welded along the ring at regular intervals, each carrying a $600-\mathrm{mL}$ culture bottle and a temperature probe. To ensure aerobic conditions in the culture bottles throughout the duration of the experiment, the inside of the culture bottles was connected to the atmosphere through a latex tube. To attain the same environmental conditions (e.g., water temperature and water disturbance) found in each river, the experimental apparatus was submerged under river water at a depth of $50 \mathrm{~cm}$.

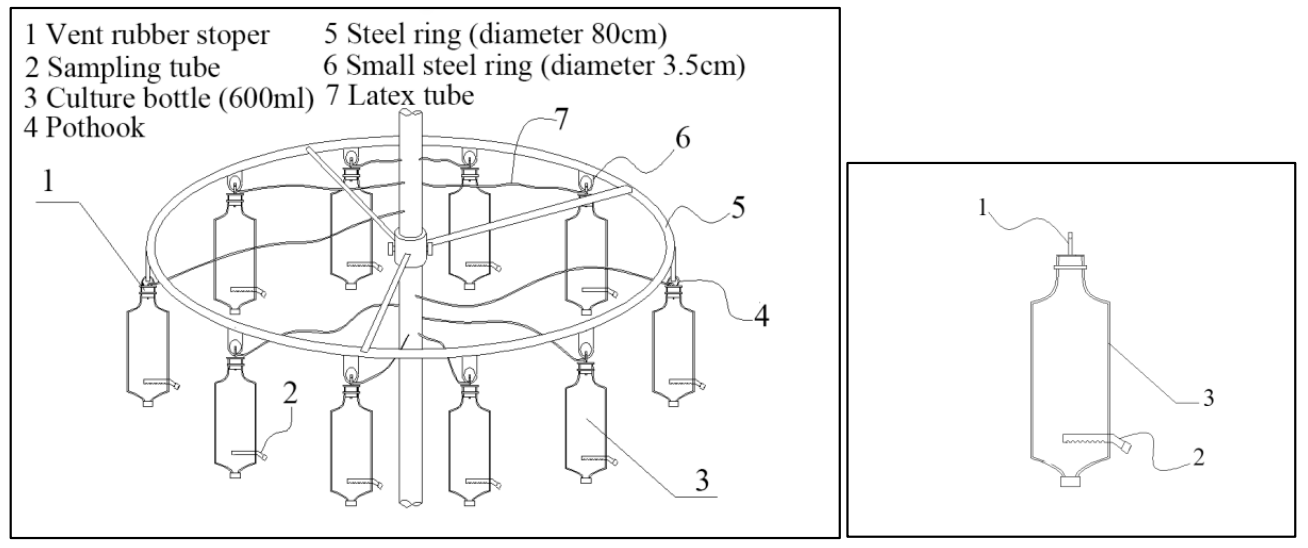

Figure 2. Diagram of the experimental apparatus used in this study.

We set up and performed an experiment in each river to measure $\mathrm{N}$ reduction rates and investigate the effects of environmental factors ( $\mathrm{DO}, \mathrm{pH}, \mathrm{SS}$, velocity and water flow) on $\mathrm{N}$ reduction rates under in-situ riverine conditions. The experiment consisted of two treatments, a control and a microbial inhibition treatment, the latter consisting in the addition of $2 \mathrm{~mL} 0.5 \% \mathrm{HgCl}_{2}$. For the controls, which reflected $\mathrm{N}$ reduce under typical riverine conditions, three culture bottles were filled with river water collected near both river shores and from the open channel at a depth of $50 \mathrm{~cm}$. For the inhibition treatments, three culture bottles were filled with water and added with $2 \mathrm{~mL} 0.5 \% \mathrm{HgCl}_{2}$, thereby reflecting $\mathrm{N}$ reduce in river water without microbial activity. The water bottles were sealed with a rubber stopper to prevent air exchanges through the bottle top and hanged in the apparatus (Figure 2), and then were placed in the river water.

To avoid disturbing suspended solids settled at the bottom of the bottles, the experimental apparatus was taken out of the water slowly after reaching the preset incubation time (1 day) and then water samples were immediately collected from the culture bottles in the field. Samples of culture water from the upper layer of each bottle were collected from a side sampling port, while samples of water and suspended solids from the bottom of each bottle were collected from a bottom sampling port. The volume of the upper and lower parts of water was measured with a measuring cylinder after being transported back to the laboratory. Water samples were placed in ice for transport to the laboratory, filtered (Whatman GF/C filters, $0.45 \mu \mathrm{m}$ pore size) and frozen until analysis.

Total $\mathrm{N}(\mathrm{TN}), \mathrm{NH}_{4}{ }^{+}-\mathrm{N}, \mathrm{NO}_{3}{ }^{-}-\mathrm{N}, \mathrm{NO}_{2}{ }^{-}-\mathrm{N}$ and a set of physico-chemical parameters were measured in each river in spring, summer, autumn and winter. The original water was analyzed for TN using potassium persulfate oxidation with detection limits of $0.001 \mathrm{mg} \cdot \mathrm{L}^{-1}$, and suspended solids were measured by weight method with detection limits of $0.0001 \mathrm{mg} \cdot \mathrm{L}^{-1}$. Filtered water was analyzed for $\mathrm{NH}_{4}{ }^{+}-\mathrm{N}, \mathrm{NO}_{3}{ }^{-}-\mathrm{N}$ and $\mathrm{NO}_{2}{ }^{-}-\mathrm{N}$ using a flow injection analyzer with detection limits of $0.1,0.01$ and $0.01 \mathrm{mg} \cdot \mathrm{L}^{-1}$, respectively (Skalar Analytical, Breda, The Netherlands). The DIN was calculated by summing the $\mathrm{NH}_{4}{ }^{+}-\mathrm{N}, \mathrm{NO}_{3}{ }^{-}-\mathrm{N}$ and $\mathrm{NO}_{2}{ }^{-}-\mathrm{N}$. At each sampling site, a multi-parameter water 
quality probe (YSI Inc., Yellow Springs, OH, USA) was used to measure water temperature, DO and $\mathrm{pH}$, and the River Surveyor M9 (SonTek, Xylem Inc., Rye Brook, NY, USA) was used to measure water velocity and flow across each river's cross-section. The water temperature, $\mathrm{DO}$ and $\mathrm{pH}$ were measured only once at the beginning of the experiment, and the water velocity and flow were measured at the beginning and the end of the experiment.

\subsection{Statistical Analyses}

The rate of change in $\mathrm{N}$ concentration $\left(R_{c}\right)$ in the upper and bottom layer of each bottle was calculated using Equation (1). In the absence of microbial activity, a theoretical rate of change can be calculated for the bottom layer $\left(T_{R_{2}}\right)$ using Equation (2), which assumes that the $\mathrm{N}$ reduction in the upper bottle layer is transferred to the bottom layer. The observed rate of change in bottom water $\mathrm{N}$ concentration $\left(R_{2}\right)$ was calculated using Equation (3). The absolute $\mathrm{N}$ reductions rates $\left(R_{a}\right)$ was calculated using Equation (4), which quantifies the total reduction rates of different $\mathrm{N}$ forms.

$$
\begin{gathered}
R_{c}=\frac{C_{0}-C_{x}}{C_{0}} \times 100 \\
T_{R_{2}}=\frac{C_{0}-C_{1}}{C_{0}} \times \frac{V_{1}}{V_{2}} \\
R_{2}=\frac{C_{0}-C_{2}}{C_{0}} \\
R_{a}=\frac{C_{0}-C_{0}^{\prime}}{t} \times 1000
\end{gathered}
$$

In the above equations, $C_{0}$ is the initial $\mathrm{N}$ concentrations, $C_{0}^{\prime}$ is the $\mathrm{N}$ concentrations after incubation, $\mathrm{t}$ is the incubation time, $C_{x}$ is the $\mathrm{N}$ concentrations after incubation in the upper $\left(x=1, C_{1}\right)$ and bottom $\left(x=2, C_{2}\right)$ layer of the culture bottle and $V_{1}$ and $V_{2}$ are the upper and bottom sampled water volume.

Data were checked for normality and homogeneity of variance prior to statistical analyses. Spatial and temporal differences in mean reduction rates among sites and seasons were tested with one-way analysis of variance (ANOVA) followed by Fisher's Least Significant Difference (LSD) test. Relationships between reduction rates and measured environmental variables were examined with correlation and principal component analysis (PCA). All statistical analyses were performed in SPSS version 19.0 (SPSS Inc., Chicago, IL, USA).

\section{Results}

\subsection{Reduce Processes of Different N Forms}

Concentrations of TN in the upper and bottom layers changed significantly after incubation (Figure 3). Compared to initial TN concentrations, upper TN concentrations decreased and bottom concentrations increased in spring, autumn and winter, while both upper and bottom TN concentrations decreased in summer compared to initial TN concentrations. This general pattern was observed across all treatments and sites, although rates of change differed among treatments, sites and seasons. Percentage changes in TN concentrations were $6.41-79.19 \%$ for control upper water, $-44.94-60.47 \%$ for control bottom water, $7.02-61.26 \%$ for inhibitor-treated upper water and $-43.92-48.93 \%$ for inhibitor-treated bottom water. TN reduced from the upper layer was transferred to the bottom layer in both treatments in spring, autumn and winter, suggesting that sedimentation of suspended solids was the primary TN reduce process in these seasons. Summer results suggested that microbial activity played an important role in TN reduction. 

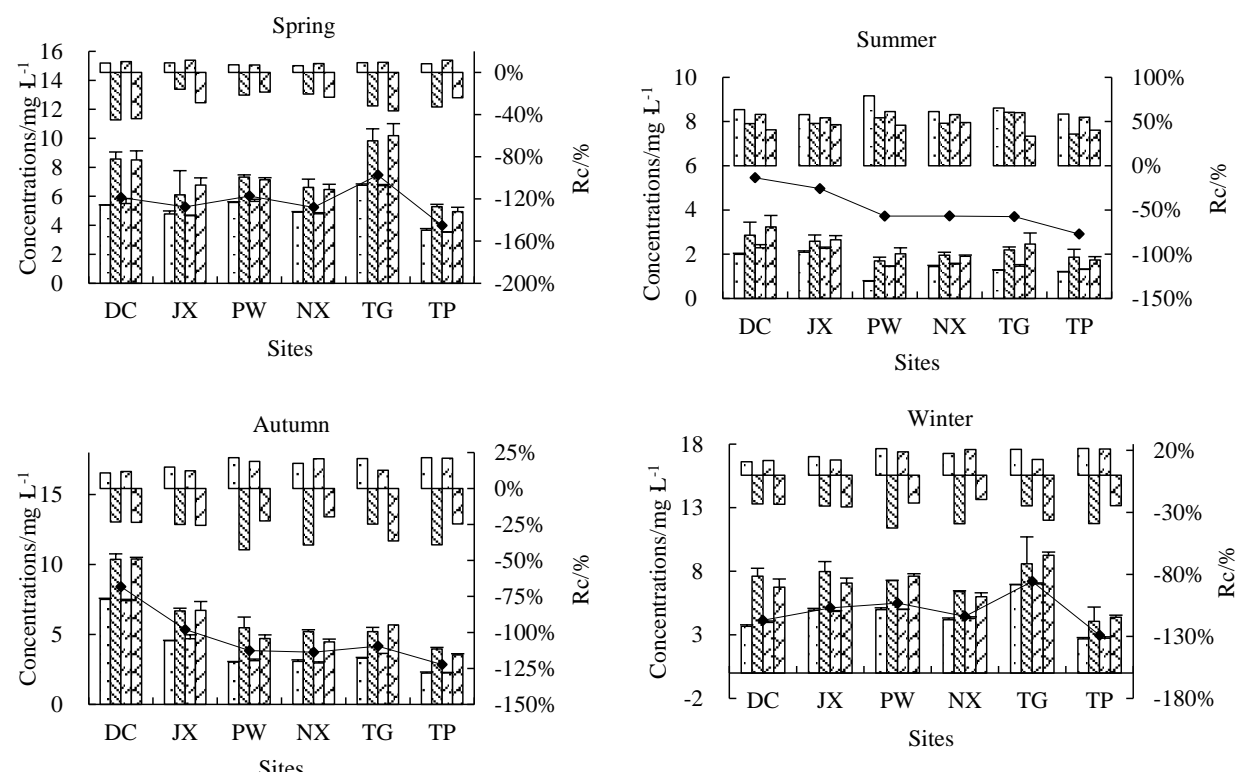

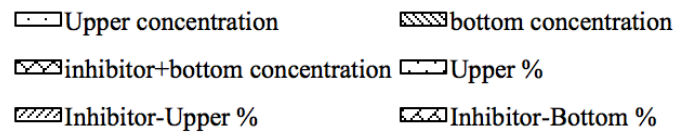$$
\begin{aligned}
& \text { Inhibitor+upper concentration } \\
& \rightarrow \text { Bottom \% } \\
& \rightarrow \text { - Initial concentration }
\end{aligned}
$$

Figure 3. Initial TN (total N) concentrations (line), final upper- and bottom-layer TN concentrations (lower histogram) and percent change from initial TN concentrations (upper histogram). A negative percentage indicates an increase in concentrations and vice versa.

A scatterplot of the theoretical vs. measured rate of change for the bottom layer shows that most spring, autumn and winter data points are distributed in quadrant II, close to the $y=-x$ line, while summer data points are located in quadrant I (Figure 4). These results indicate that sedimentation was the main $\mathrm{TN}$ reduction process in spring, autumn and winter, while microbial activity contributed significantly in summer.

Rates of change in upper and bottom $\mathrm{NH}_{4}{ }^{+}-\mathrm{N}$ concentrations showed significant differences among seasons and sampling sites, although no clear seasonal and spatial pattern emerged (Figure 5). In general, $\mathrm{NH}_{4}{ }^{+}-\mathrm{N}$ concentrations decreased in most sites, especially in $\mathrm{PW}$, which showed an average percentage decrease of $96.25 \%$. In some sites, such as DC, $\mathrm{PW}$ and TP, a decrease in bottom $\mathrm{NH}_{4}{ }^{+}-\mathrm{N}$ was observed in inhibitor-treated bottles, suggesting the occurrence of chemical $\mathrm{N}$ reduce processes other than biological activity. Controls showed higher $\mathrm{NH}_{4}{ }^{+}-\mathrm{N}$ rates of change than inhibition treatments, illustrating the role of microorganisms in processing $\mathrm{N}$ in natural water bodies. 

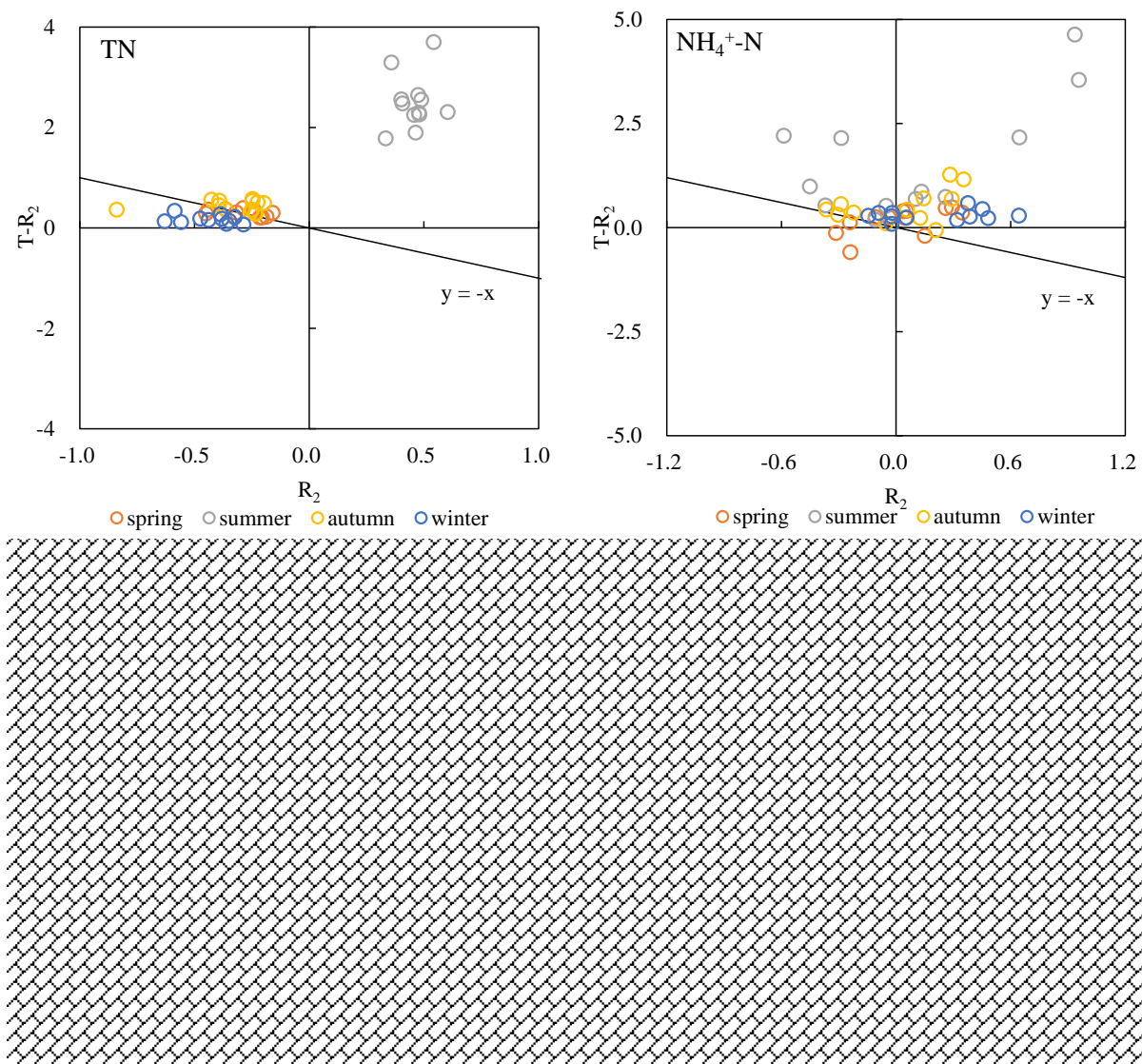

Figure 4. Scatterplot of T- $R_{2}$ (theoretical rate of change of bottom $N$ concentrations, $y$-axis) vs $R_{2}$ (experimentally measured rate of change of bottom $\mathrm{N}$ concentrations, $x$-axis). Points lying on the $\mathrm{y}=-\mathrm{x}$ line exhibit upper concentrations loss rates equaling bottom concentrations increase rates as a result of physical deposition in absence of microbial activity.
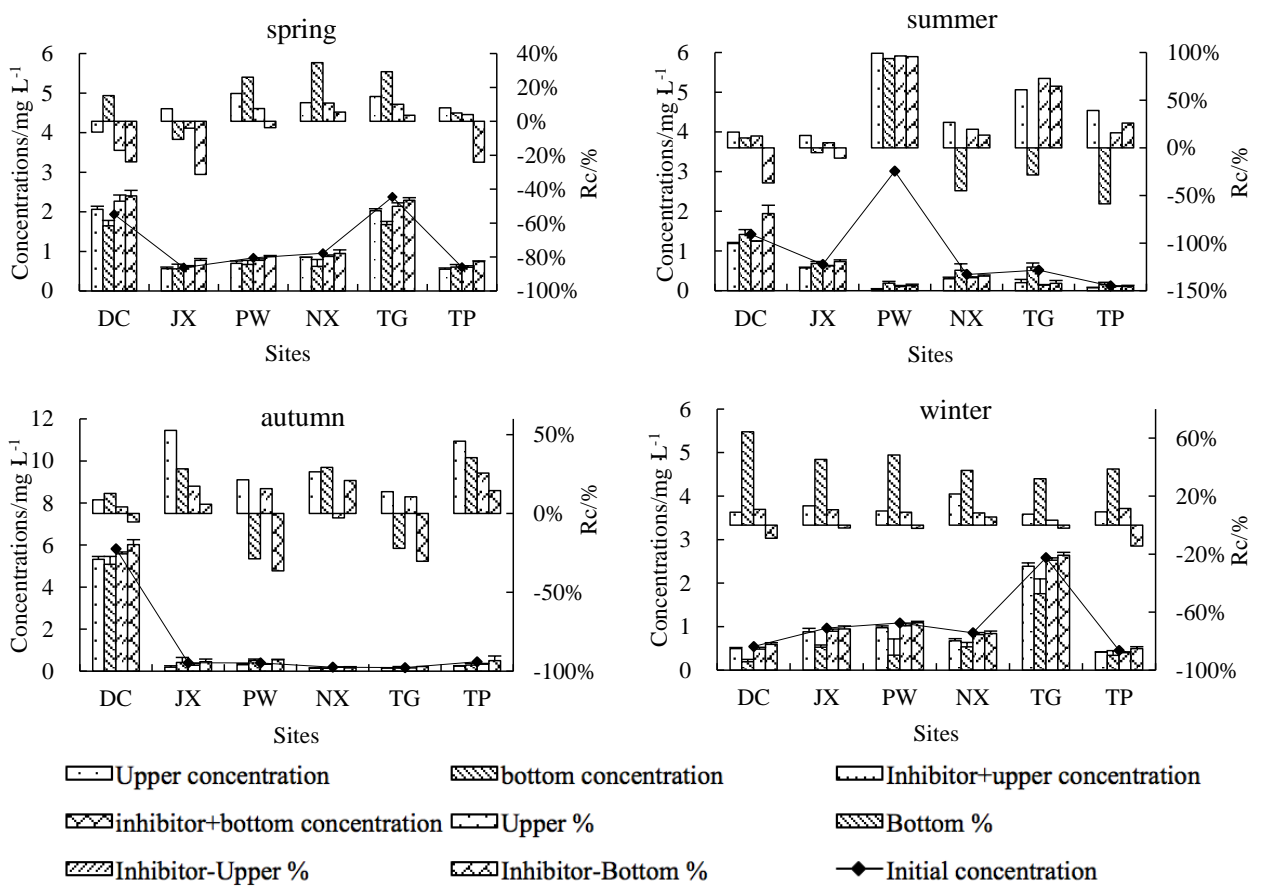

Inhibitor+upper concentration ॠWB Bottom \%

$\longrightarrow$ Initial concentration

Figure 5. Initial $\mathrm{NH}_{4}{ }^{+}-\mathrm{N}$ concentrations (line), final upper- and bottom-layer $\mathrm{NH}_{4}{ }^{+}-\mathrm{N}$ concentrations (lower histogram) and percent change from initial $\mathrm{NH}_{4}{ }^{+}-\mathrm{N}$ concentration (upper histogram). A negative percentage indicates an increase in concentrations and vice versa. 
Almost all data points representing the relationship between theoretical and observed rate of change in bottom $\mathrm{NH}_{4}{ }^{+}-\mathrm{N}$ concentration lie in quadrant I (25 points) and II (19 points), with only two points appearing in each of quadrant III and IV, respectively (Figure 4). Most points in quadrant II lie above the $y=-x$ line, suggesting the occurrence of biochemical reduce of $\mathrm{NH}_{4}{ }^{+}-\mathrm{N}$ in natural water.

Upper $\mathrm{NO}_{3}{ }^{-}-\mathrm{N}$ concentrations decreased while bottom $\mathrm{NO}_{3}{ }^{-}-\mathrm{N}$ concentrations increased at all sites in spring (except DC), autumn and winter (Figure 6). At all sites rates of change were higher in autumn and winter than in spring (1.95-12.39\% for upper control water, $-4.06-7.21 \%$ for bottom control water, $1.06-4.55 \%$ for inhibitor-treated upper water and $-3.63-8.48 \%$ for inhibitor-treated bottom water). All sites had the lowest rates of change in summer $(-12.28-16.93 \%)$ with the exception of PW, which showed an average summer rate of change of $-169.75 \%$. Percentage decreases were higher in upper control water than in inhibitor-treated upper water, suggesting that biological activity played a key role in the $\mathrm{NO}_{3}{ }^{-}-\mathrm{N}$ reduce process relative to physical deposition.
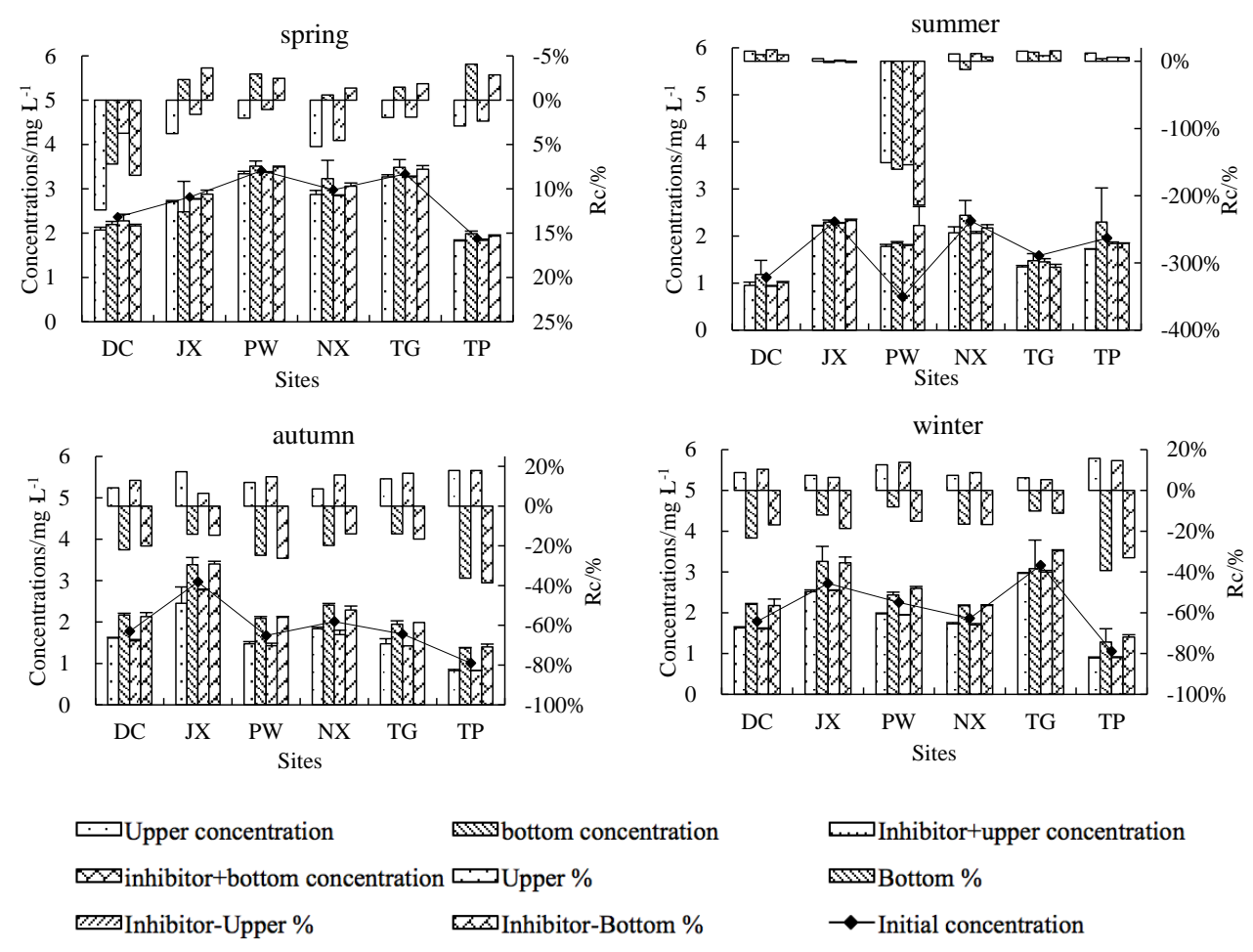

Figure 6. Initial $\mathrm{NO}_{3}{ }^{-}-\mathrm{N}$ concentrations (line), final upper- and bottom-layer $\mathrm{NO}_{3}{ }^{-}-\mathrm{N}$ concentrations (lower histogram) and percent change from initial $\mathrm{NO}_{3}{ }^{-}-\mathrm{N}$ concentrations (upper histogram). A negative percentage indicates an increase in concentrations and vice versa.

In the plot of theoretical vs. observed bottom rates of change, most summer data points lie in quadrant I (Figure 4), indicating significant biological activity. Two data points belonging to PW and not shown in Figure 4 are located in quadrant III (coordinates [1.6, 7.0] and [2.1, 5.7]). The remaining points are located in quadrant II and above the $\mathrm{y}=-\mathrm{x}$ line, illustrating the influence of biochemical activity.

Being an intermediate of nitrification and denitrification, rates of change in $\mathrm{NO}_{2}{ }^{-} \mathrm{N}$ concentrations are closely related to those of $\mathrm{NH}_{4}{ }^{+}-\mathrm{N}$ and $\mathrm{NO}_{3}{ }^{-}-\mathrm{N}$. A decrease in $\mathrm{NO}_{2}{ }^{-}-\mathrm{N}$ concentrations was observed in $80 \%$ of samples, with the highest rates of change occurring in summer (-66.30-83.67\%) (Figure 7). 

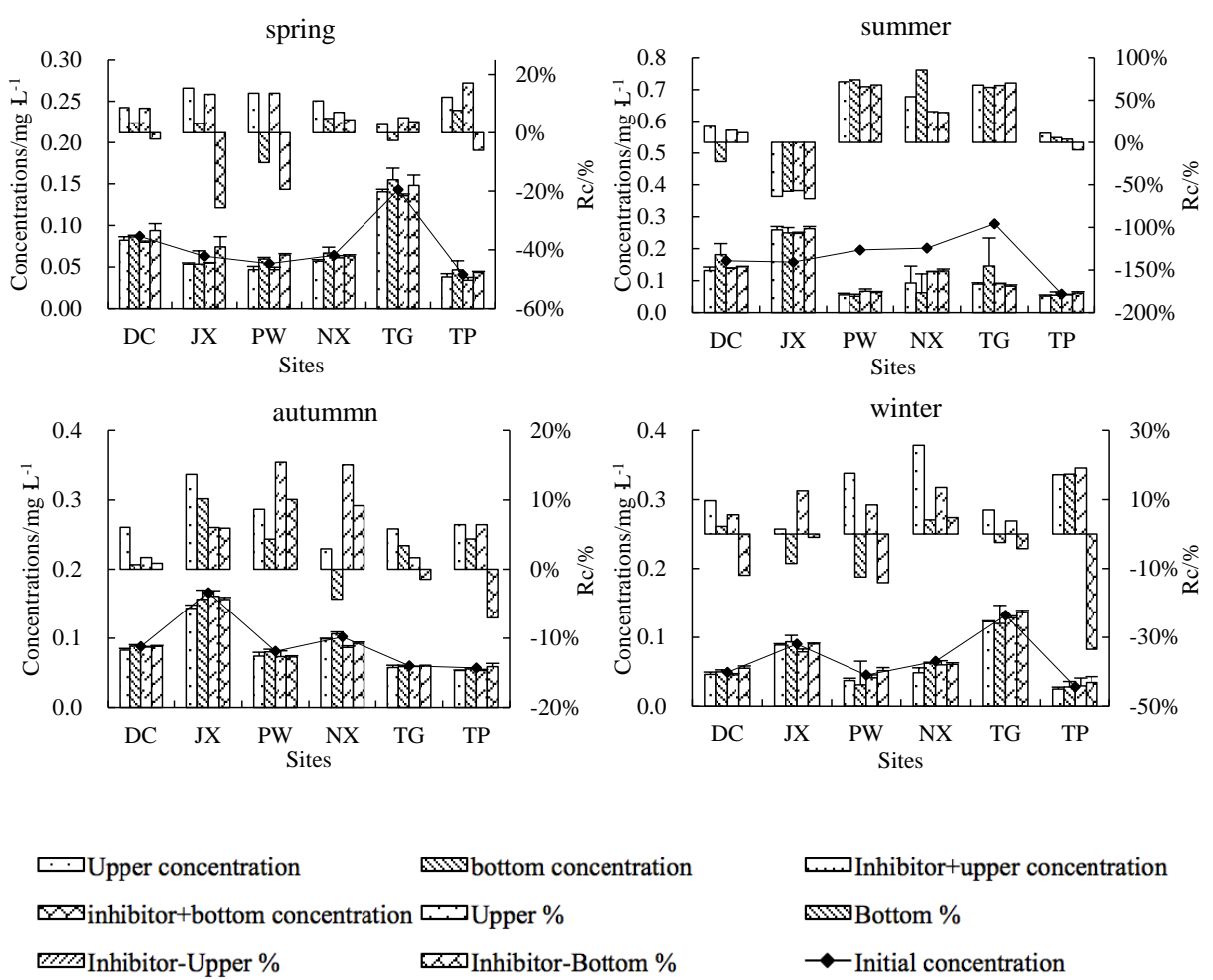

Figure 7. Initial $\mathrm{NO}_{2}{ }^{-}-\mathrm{N}$ concentrations (line), final upper- and bottom-layer $\mathrm{NO}_{2}{ }^{-}-\mathrm{N}$ concentrations (lower histogram) and percent change from initial $\mathrm{NO}_{2}{ }^{-}-\mathrm{N}$ concentrations (upper histogram). A negative percentage indicates an increase in concentrations and vice versa.

Most data points illustrating the relationship between theoretical and observed bottom rates of change lie in quadrant I (19 points) and quadrant II (27 points), with only two points in quadrants III and IV (Figure 4). Points located in quadrant II are above the $y=-x$ line, indicating a significant influence of biological activity across the four seasons.

\subsection{Spatial and Seasonal Differences in N Reduction Rates}

Across the six rivers and four sampled seasons, $\mathrm{TN}, \mathrm{NH}_{4}{ }^{+}-\mathrm{N}, \mathrm{NO}_{3}{ }^{-}-\mathrm{N}$ and $\mathrm{NO}_{2}{ }^{-}-\mathrm{N}$ reduction rates ranged from $105.4 \pm 25.3$ to $1458.8 \pm 98.4 \mathrm{mg} \cdot\left(\mathrm{m}^{3} \cdot \mathrm{d}\right)^{-1}, 33.1 \pm 12.3$ to $440.9 \pm 33.1 \mathrm{mg} \cdot\left(\mathrm{m}^{3} \cdot \mathrm{d}\right)^{-1}$, $56.3 \pm 22.7$ to $332.1 \pm 61.9 \mathrm{mg} \cdot\left(\mathrm{m}^{3} \cdot \mathrm{d}\right)^{-1}$ and $0.4 \pm 0.3$ to $31.8 \pm 9.0 \mathrm{mg} \cdot\left(\mathrm{m}^{3} \cdot \mathrm{d}\right)^{-1}$, respectively (Figure 8 ). TN reduction rates were significantly higher in summer and autumn than in other seasons $(p<0.05)$ at all sites but TP site. No significant differences of seasonal average TN reduction rates were observed across sampling sites except TP site $(p>0.05)$. Reduction rates of $\mathrm{NH}_{4}{ }^{+}-\mathrm{N}, \mathrm{NO}_{3}{ }^{-}-\mathrm{N}$ and $\mathrm{NO}_{2}{ }^{-}-\mathrm{N}$ were higher in summer and autumn than in the remaining seasons at most sites, while in DC high spring $\mathrm{NH}_{4}{ }^{+}-\mathrm{N}$ and $\mathrm{NO}_{3}{ }^{-}-\mathrm{N}$ concentrations were observed. All six sites had significantly higher average $\mathrm{NO}_{3}{ }^{-}-\mathrm{N}$ reduction rates in autumn compared to spring, while $\mathrm{NO}_{2}{ }^{-}-\mathrm{N}$ reduction rates were highest in summer $(p<0.05)$. 

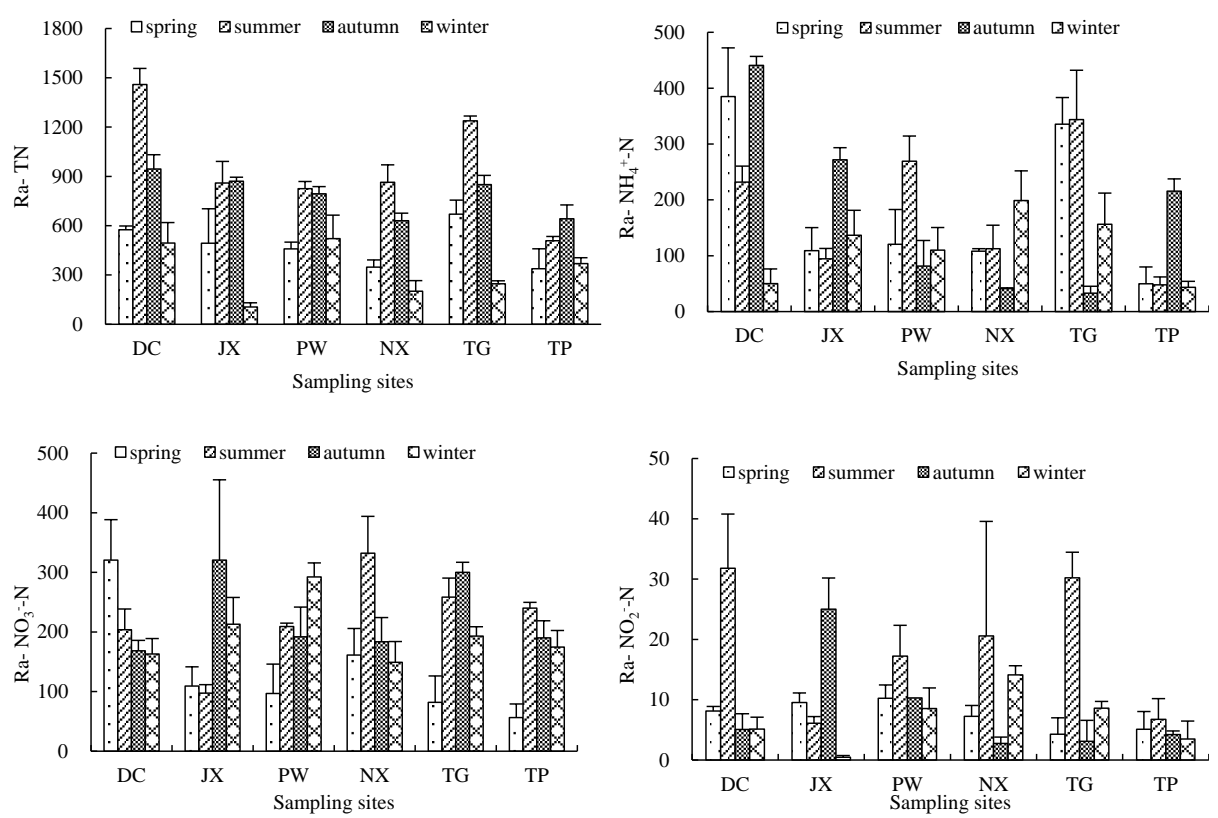

Figure 8. $\mathrm{TN}, \mathrm{NH}_{4}{ }^{+}-\mathrm{N}, \mathrm{NO}_{3}{ }^{-}-\mathrm{N}$ and $\mathrm{NO}_{2}{ }^{-}-\mathrm{N}$ reduction rates in the sampled rivers in different seasons $\left(\mathrm{mg} \cdot\left(\mathrm{m}^{3} \cdot \mathrm{d}\right)^{-1}\right)$.

We observed remarkable differences in $\mathrm{NH}_{4}{ }^{+}-\mathrm{N}, \mathrm{NO}_{3}{ }^{-}-\mathrm{N}$ and $\mathrm{NO}_{2}{ }^{-}-\mathrm{N}$ reduction rates within the same season across rivers or within the same river across seasons. In spring, the reduction rates of $\mathrm{NH}_{4}{ }^{+}-\mathrm{N}$ in $\mathrm{DC}$ and $\mathrm{TG}$ and $\mathrm{NO}_{3}{ }^{-}-\mathrm{N}$ in DC were significantly higher than in other rivers $(p<0.05)$, while no significant difference was observed in $\mathrm{NO}_{2}{ }^{-}-\mathrm{N}$ reduction rates among rivers $(p>0.05)$. In summer, reduction rates of $\mathrm{NH}_{4}{ }^{+}-\mathrm{N}$ in TG, $\mathrm{NO}_{3}{ }^{-}-\mathrm{N}$ in $\mathrm{NX}$ and TG were significantly higher than in other rivers $(p<0.05)$, while $\mathrm{NO}_{2}{ }^{-}-\mathrm{N}$ reduction rates were significantly lower in JX and TP compared to others $(p<0.05)$. In autumn, $\mathrm{DC}$ had a significantly higher $\mathrm{NH}_{4}{ }^{+}-\mathrm{N}$ reduction rate than other rivers, while reduction rates of $\mathrm{NO}_{3}{ }^{-}-\mathrm{N}$ in JX, TG and $\mathrm{NO}_{2}{ }^{-}-\mathrm{N}$ in JX were significantly higher compared to other rivers $(p<0.05)$. In winter, the highest $\mathrm{NH}_{4}{ }^{+} \mathrm{N}_{1} \mathrm{NO}_{3}{ }^{-}-\mathrm{N}$ and $\mathrm{NO}_{2}{ }^{-}-\mathrm{N}$ reduction rates were observed in NX, PW and NX, respectively, while TN reduction rates were higher in DC than in other sites across the four seasons.

\subsection{Microbial and Non-Microbial DIN Reduction Rates}

Different $\mathrm{N}$ reduce processes occurring in natural freshwater ecosystems, including microbial and non-microbial mechanisms, result in spatial and seasonal differences in DIN reduction rates. The relative contributions of microbial and non-microbial processes to DIN reduce differed among rivers and seasons (Figure 9). Across all sites and seasons, microbial DIN (MDIN) reduction rates ranged from -145.3 to $498.9 \mathrm{mg} \cdot\left(\mathrm{m}^{3} \cdot \mathrm{d}\right)^{-1}$, with an average of $96.0 \pm 46.4 \mathrm{mg} \cdot\left(\mathrm{m}^{3} \cdot \mathrm{d}\right)^{-1}$, while non-microbial DIN (nMDIN) reduction rates ranged from 75.6 to $582.3 \mathrm{mg} \cdot\left(\mathrm{m}^{3} \cdot \mathrm{d}\right)^{-1}$, with an average of $288.1 \pm 67.8 \mathrm{mg} \cdot\left(\mathrm{m}^{3} \cdot \mathrm{d}\right)^{-1}$. These results suggest that non-microbial processes were generally the primary DIN reduction mechanism. 

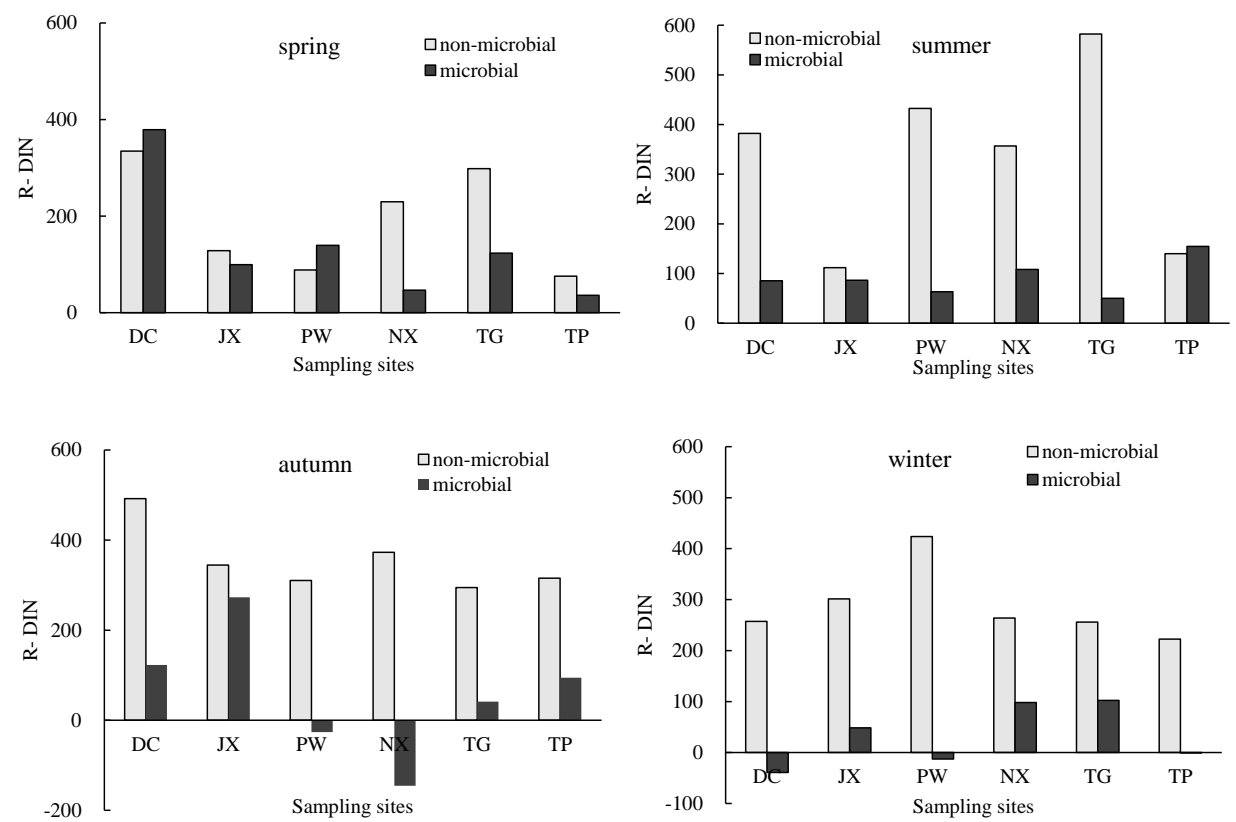

Figure 9. Microbial and non-microbial DIN (dissolved inorganic $\mathrm{N}$ ) reduction rates at sampling sites in different seasons $\left(\mathrm{mg} \cdot\left(\mathrm{m}^{3} \cdot \mathrm{d}\right)^{-1}\right)$.

In spring, MDIN and nMDIN reduction rates were higher in DC than in other sites. In summer, nMDIN reduction rates were generally higher than MDIN rates at all sites except TP, where nMDIN and MDIN rates were similar. In autumn and winter, nMDIN reduction rates were higher than MDIN rates at all sites. Negative MDIN reduction rates observed in PW, DC and NX might be due to sediment resuspension offsetting the effect of microbial reduce. The proportions of DIN reduction rates and $\mathrm{N}$ load attributable to microbial and non-microbial processes are shown in Table 2.

Table 2. Proportion of DIN (dissolved inorganic N) reduction rates and $\mathrm{N}$ load attributable to microbial and non-microbial processes (\%).

\begin{tabular}{|c|c|c|c|c|c|c|c|c|c|}
\hline \multirow{2}{*}{ Sites } & & \multicolumn{2}{|c|}{ Spring } & \multicolumn{2}{|c|}{ Summer } & \multicolumn{2}{|c|}{ Autumn } & \multicolumn{2}{|c|}{ Winter } \\
\hline & & DIN & $\mathbf{N}$ & DIN & $\mathbf{N}$ & DIN & $\mathbf{N}$ & DIN & $\mathbf{N}$ \\
\hline DC & & 46.9 & 5.7 & 81.8 & 7.0 & 80.0 & 5.8 & - & 6.2 \\
\hline JX & & 56.4 & 2.4 & 56.4 & 2.2 & 55.8 & 6.4 & 86.2 & 5.9 \\
\hline PW & non- & 38.8 & - & 87.2 & 7.7 & - & 8.1 & - & 7.7 \\
\hline $\mathrm{NX}$ & microbial & 83.1 & 4.4 & 76.7 & 9.6 & - & 10.0 & 72.9 & 5.9 \\
\hline TG & & 70.8 & 4.0 & 92.1 & 15.7 & 87.6 & 7.1 & 71.5 & 3.6 \\
\hline $\mathrm{TP}$ & & 67.8 & - & 47.5 & 4.8 & 77.0 & 11.1 & - & 7.5 \\
\hline $\mathrm{DC}$ & & 53.1 & 6.4 & 18.2 & 1.6 & 20.0 & 1.5 & - & - \\
\hline $\mathrm{JX}$ & & 43.6 & 1.9 & 43.6 & 1.7 & 44.2 & 5.1 & 13.8 & 0.9 \\
\hline PW & & 61.2 & 2.3 & 12.8 & 1.1 & - & - & - & - \\
\hline NX & microbial & 16.9 & 0.9 & 23.3 & 2.9 & - & - & 27.1 & 2.2 \\
\hline TG & & 29.2 & 1.7 & 7.9 & 1.3 & 12.4 & 1.0 & 28.5 & 1.4 \\
\hline $\mathrm{TP}$ & & 32.2 & 0.9 & 52.5 & 5.3 & 23.0 & 3.3 & - & 0.0 \\
\hline
\end{tabular}

DIN\% and $\mathrm{N} \%$ represent the proportion of DIN reduction rates and $\mathrm{N}$ load attributable to microbial and non-microbial processes. Dashes indicate cases where percentages $<0 \%$ or $>100 \%$ were obtained.

\subsection{Factors Controlling Reduction Rates}

We investigated environmental factors that may have affected $\mathrm{N}$ reduction rates observed in our in-situ incubation experiments. We found significant correlations between $\mathrm{N}$ reduction rates and initial $\mathrm{N}$ concentrations, $\mathrm{DO}, \mathrm{pH}$, suspended solids, water velocity and flow rate (Table 3). Specifically, $\mathrm{N}$ reduction rates were positively correlated with concentrations of $\mathrm{N}, \mathrm{pH}$ and suspended solids 
and negatively correlated with $\mathrm{DO}$, water velocity and flow rate. $\mathrm{N}$ reduce is a complex process influenced by a variety of environmental factors directly and indirectly, and the reduction of each $\mathrm{N}$ form considered in this study was also influenced by one or more factors.

Table 3. Correlation coefficients between $\mathrm{N}$ reduction rates and environmental factors.

\begin{tabular}{|c|c|c|c|c|c|c|c|c|c|}
\hline \multicolumn{2}{|c|}{ Reduction Rates } & \multirow{2}{*}{$\begin{array}{c}\mathrm{NH}_{4}{ }^{+}-\mathrm{N} \\
-\end{array}$} & \multirow{2}{*}{$\begin{array}{c}\mathrm{NO}_{3}^{-}-\mathrm{N} \\
-\end{array}$} & \multirow{2}{*}{$\begin{array}{l}\mathrm{NO}_{2}{ }^{-}-\mathbf{N} \\
0.557(+)\end{array}$} & \multirow{2}{*}{$\begin{array}{c}\text { DO } \\
0.272(-)\end{array}$} & \multirow{2}{*}{$\begin{array}{c}\text { Suspended Solids } \\
-\end{array}$} & \multirow{2}{*}{$\begin{array}{c}\mathrm{pH} \\
0.304(+)\end{array}$} & \multirow{2}{*}{$\begin{array}{l}\text { Velocity } \\
0.163(-)\end{array}$} & \multirow{2}{*}{$\begin{array}{c}\text { Water Flow } \\
-\end{array}$} \\
\hline & control & & & & & & & & \\
\hline $\mathrm{TN}$ & non-microbial & $0.243(+)$ & - & $0.255(+)$ & - & - & - & $0.261(-)$ & $0.242(-)$ \\
\hline & microbial & - & - & $0.291(+)$ & $0.329(-)$ & - & - & - & - \\
\hline \multirow{3}{*}{$\mathrm{NH}_{4}{ }^{+}-\mathrm{N}$} & control & $0.455(+)$ & - & $0.237(+)$ & - & $0.142(+)$ & $0.249(+)$ & $0.243(-)$ & $0.242(-)$ \\
\hline & non-microbial & $0.296(+)$ & - & $0.427(+)$ & - & - & $0.327(+)$ & $0.190(-)$ & $0.138(-)$ \\
\hline & microbial & $0.226(+)$ & - & - & - & $0.460(+)$ & - & - & - \\
\hline \multirow{3}{*}{$\mathrm{NO}_{3}{ }^{-}-\mathrm{N}$} & control & - & - & - & $0.142(-)$ & - & - & - & - \\
\hline & non-microbial & - & - & - & $0.287(-)$ & - & - & - & - \\
\hline & microbial & & - & - & - & $0.206(+)$ & & - & - \\
\hline \multirow{3}{*}{$\mathrm{NO}_{2}{ }^{-}-\mathrm{N}$} & control & - & - & $0.502(+)$ & - & - & $0.249(+)$ & - & - \\
\hline & non-microbial & - & - & $0.451(+)$ & - & - & - & - & - \\
\hline & microbial & - & - & $0.218(+)$ & $0.128(-)$ & - & - & - & - \\
\hline \multirow{2}{*}{ DIN } & non-microbial & - & - & $0.279(+)$ & $0.170(-)$ & - & $0.418(+)$ & $0.198(-)$ & $0.134(-)$ \\
\hline & microbial & - & - & - & - & $0.416(+)$ & - & - & - \\
\hline
\end{tabular}

Values represent the fitting coefficient for correlation; "-" represent no correlation; (+), (-) represent the positive or negative correlation.

We performed PCA analysis to explore correlations among variables and assess the relative importance of different factors. PCA results showed three significant components illustrating the effects of different environmental variables on $\mathrm{N}$ reduce in each season (Table 4). In spring, $\mathrm{N}$ concentrations and multiple environmental variables were the main factors affecting reduce processes, with $55.32 \%$ of the total variance explained. In summer, $\mathrm{N}$ concentrations and two water quality variables (DO and $\mathrm{pH}$ ) explained $45.72 \%$ and $33.49 \%$ of the total variance, respectively, thus representing the main factors related to $\mathrm{N}$ reduce processes. In autumn, water velocity and flow and $\mathrm{N}$ concentrations were the most important factors, with $50.51 \%$ of the total variance explained, while $\mathrm{N}$ concentrations was the strongest driver in winter (53.45\% of the total variance explained).

Table 4. PCA (principal component analysis) loadings, eigenvalues and percentages of variance explained for environmental parameters measured at all sampling sites across four seasons.

\begin{tabular}{|c|c|c|c|c|c|c|c|c|c|c|c|c|}
\hline \multirow{2}{*}{ Parameters } & \multicolumn{3}{|c|}{ Spring } & \multicolumn{3}{|c|}{ Summer } & \multicolumn{3}{|c|}{ Autumn } & \multicolumn{3}{|c|}{ Winter } \\
\hline & PC1 & PC2 & PC3 & PC1 & PC2 & PC3 & PC1 & PC2 & PC3 & PC1 & PC2 & PC3 \\
\hline $\mathrm{DO}$ & -0.766 & 0.033 & -0.425 & -0.219 & 0.834 & 0.487 & 0.281 & 0.330 & -0.794 & -0.242 & 0.813 & 0.301 \\
\hline velocity & -0.403 & 0.452 & 0.756 & -0.734 & -0.541 & 0.356 & -0.790 & 0.347 & 0.473 & -0.738 & 0.597 & -0.247 \\
\hline flow & -0.824 & -0.083 & 0.341 & -0.718 & -0.452 & 0.521 & -0.762 & -0.107 & 0.543 & -0.765 & 0.449 & -0.446 \\
\hline SS & 0.279 & -0.934 & -0.045 & 0.734 & -0.329 & 0.516 & 0.804 & 0.457 & 0.354 & -0.246 & 0.000 & 0.964 \\
\hline $\mathrm{NO}_{3}{ }^{-}$ & 0.623 & 0.647 & -0.412 & -0.765 & 0.100 & -0.523 & 0.794 & 0.597 & 0.080 & 0.986 & 0.024 & -0.012 \\
\hline $\mathrm{NO}_{2}^{-}$ & 0.892 & 0.036 & 0.268 & 0.516 & 0.827 & -0.108 & 0.732 & 0.578 & 0.342 & 0.909 & 0.195 & -0.221 \\
\hline Eigenvalue & 4.979 & 1.595 & 1.278 & 4.115 & 3.014 & 1.499 & 4.546 & 2.256 & 1.738 & 4.811 & 2.147 & 1.409 \\
\hline$\%$ of variance & 55.320 & 17.719 & 14.197 & 45.720 & 33.491 & 16.658 & 50.508 & 25.062 & 19.312 & 53.452 & 23.856 & 15.659 \\
\hline
\end{tabular}

Absolute loading values $>0.750$ are indicated in bold.

\section{Discussion}

\subsection{Reduce Processes}

Transformation and transport of $\mathrm{N}$ compounds in river water are complex processes involving physical, chemical and biological mechanisms. Basic $\mathrm{N}$ transformation processes include nitrification and denitrification [17], while vertical migration occurs through settlement of adsorbed compounds and desorption. Nitrification is typically considered an obligated aerobic and chemoautotrophic process [18], while denitrification is primarily a facultative heterotrophic process and occurs under 
low DO conditions $[19,20]$. We observed differences in $\mathrm{TN}, \mathrm{NH}_{4}{ }^{+}-\mathrm{N}, \mathrm{NO}_{3}{ }^{-}-\mathrm{N}$ and $\mathrm{NO}_{2}{ }^{-}-\mathrm{N}$ migration and transformation processes across different seasons (Figure 3 through Figure 7). The contribution of biochemical processes to TN reduction was weak in spring and autumn but strong in summer, while physical sedimentation dominated in winter (Figure 4). Biochemical transformation of $\mathrm{NH}_{4}{ }^{+}-\mathrm{N}$, $\mathrm{NO}_{3}{ }^{-}-\mathrm{N}$ and $\mathrm{NO}_{2}{ }^{-}-\mathrm{N}$ occurred in our cultures and dominated in summer and autumn but became secondary in spring and winter. Higher temperatures in summer and autumn resulted in a strong contribution of microbial activities to the $\mathrm{N}$ cycle through nitrification and denitrification [21]. Nitrifying bacteria can convert $\mathrm{NH}_{4}{ }^{+}$to $\mathrm{NO}_{2}{ }^{-}$and then $\mathrm{NO}_{3}{ }^{-}$, as shown by our summer results in $\mathrm{PW}$, where $\mathrm{NH}_{4}{ }^{+}-\mathrm{N}$ decreased by $96.25 \%, \mathrm{NO}_{2}{ }^{-} \mathrm{N}$ decreased by $69.93 \%$ and $\mathrm{NO}_{3}{ }^{-}-\mathrm{N}$ increased by $169.75 \%$. The significantly greater decrease in $\mathrm{NH}_{4}{ }^{+}-\mathrm{N}$ in $\mathrm{PW}$ compared to other sites may be due to high concentrations of suspended solids $(348 \mathrm{mg} / \mathrm{L})$, which can promote nitrification in rivers $[16,22]$. Contrary to expectations, $\mathrm{N}$ concentrations decreased both in the upper and bottom culture water treated with a microbial inhibitor, with the decrease being particularly obvious for $\mathrm{NH}_{4}{ }^{+}-\mathrm{N}$ (Figure 4). This finding could be due to $\mathrm{NH}_{4}{ }^{+}$volatilization resulting in a decrease in $\mathrm{NH}_{4}{ }^{+}-\mathrm{N}$ concentrations in the absence of microbial activity [23]. The 11 data points showing a decrease in $\mathrm{NH}_{4}{ }^{+}-\mathrm{N}$ mostly came from summer and autumn samples from NX, TG and TP, where $\mathrm{NH}_{4}{ }^{+}$volatilization may be associated with extensive farmland areas around and upstream of the sampling sites (Figure 1), resulting in fertilizers being washed into rivers by rainfall. Suspended solids not only adsorb $\mathrm{N}$ compounds to their surface, but can also absorb $\mathrm{N}$ [24], which may explain the greater increase in bottom layer TN compared to the observed decrease in the corresponding upper layer (Figure 4, upper left panel). Our in-situ experiment allowed us to investigate the main processes contributing to transport and transformation of different $\mathrm{N}$ forms across different rivers and seasons. However, the current experimental design does not allow us to quantify the relative contribution of each process to different $\mathrm{N}$ forms.

\subsection{Analysis of Spatio-Temporal Differences}

Processes contributing to observed decreases in DIN $\left(\mathrm{NH}_{4}{ }^{+}, \mathrm{NO}_{3}{ }^{-}\right.$and $\left.\mathrm{NO}_{2}{ }^{-}\right)$are complex and include microbial and non-microbial mechanisms. Nitrification, the production of $\mathrm{NO}_{3}{ }^{-}$from $\mathrm{NH}_{4}{ }^{+}$, and denitrification of $\mathrm{NO}_{3}{ }^{-}$to gaseous $\mathrm{N}$ are the main microbial reduce processes. DIN can also be adsorbed by suspended solids and leave the water through deposition. These processes are affected by different river conditions.

According to the results of our in-situ experiment, reduction rates of $\mathrm{NH}_{4}{ }^{+}, \mathrm{NO}_{3}{ }^{-}$and $\mathrm{NO}_{2}{ }^{-}$ showed significant seasonal and spatial heterogeneity. In the six study rivers, $\mathrm{NH}_{4}{ }^{-}-\mathrm{N}, \mathrm{NO}_{3}{ }^{-}-\mathrm{N}$ and $\mathrm{NO}_{2}{ }^{-}-\mathrm{N}$ reduction rates ranged from $33.1 \pm 12.3$ to $440.9 \pm 33.1 \mathrm{mg} \cdot\left(\mathrm{m}^{3} \cdot \mathrm{d}\right)^{-1}, 56.3 \pm 22.7$ to $332.1 \pm 61.9 \mathrm{mg} \cdot\left(\mathrm{m}^{3} \cdot \mathrm{d}\right)^{-1}$ and $0.4 \pm 0.3$ to $31.8 \pm 9.0 \mathrm{mg} \cdot\left(\mathrm{m}^{3} \cdot \mathrm{d}\right)^{-1}$, respectively, across four seasons. Reduction rates of $\mathrm{NH}_{4}{ }^{+}-\mathrm{N}$ and $\mathrm{NO}_{2}{ }^{-}-\mathrm{N}$ were positively correlated with $\mathrm{NH}_{4}{ }^{+}-\mathrm{N}^{-}$and $\mathrm{NO}_{2}{ }^{-}-\mathrm{N}$ initial concentrations, while a similar correlation was not observed between $\mathrm{NO}_{3}{ }^{-}-\mathrm{N}$ reduction rates and initial $\mathrm{NO}_{3}{ }^{-}$concentrations (Table 3). In Lake Taihu's Zhushan Bay, a maximum $\mathrm{NH}_{3}$ oxidation rate of $224 \mathrm{mg}\left(\mathrm{m}^{3} \cdot \mathrm{d}\right)^{-1}$ was measured in relation to an $\mathrm{NH}_{3}$ concentrations of $0.85 \mathrm{mg} / \mathrm{L}$ [25], which is lower than the maximum values observed in this study. The $\mathrm{NH}_{4}{ }^{+}-\mathrm{N}$ reduction rates measured in this study including microbial (nitrification and anaerobic $\mathrm{NH}_{3}$ oxidation) and non-microbial processes showed that $39.62 \%$ of the reduce was attributable to microbial activity, indicating that our results are plausible. Several studies have reported nitrification rates in different aquatic systems. For example, nitrification rates of $249 \mathrm{mg} \mathrm{N}\left(\mathrm{m}^{2} \cdot \mathrm{d}\right)^{-1}$ and $370 \mathrm{mg} \mathrm{N}\left(\mathrm{m}^{2} \cdot \mathrm{d}\right)^{-1}$ were measured in sediments of a Lake Superior estuary and Onondaga Lake, respectively $[12,26]$. Both studies differed from our work and focused on sediment nitrification rates, though nitrification in the water column is often not negligible. The activity of nitrifying bacteria is regulated by $\mathrm{NH}_{3}-\mathrm{N}$, with $\mathrm{NH}_{3}$ oxidizing bacteria increasing significantly at high $\mathrm{NH}_{3}-\mathrm{N}$ levels, thereby promoting $\mathrm{NH}_{3}$ oxidation [27]. At the same time, suspended solids can promote nitrification by providing microbial adhesion sites [16] and can also contribute to removing $\mathrm{NH}_{4}{ }^{+}$from the water column through bottom deposition. $\mathrm{NH}_{4}{ }^{+}-\mathrm{N}$ reduction rates were negatively 
correlated with water velocity and flow rate. Previous studies have shown that heavy navigation traffic and wider river can accelerate pollutant degradation and dilution, thereby decreasing pollutant concentrations $[9,28]$. Water turbulence also affects suspended solid settlement rates. In this study, $\mathrm{NO}_{3}{ }^{-}-\mathrm{N}$ reduction rates were not correlated with $\mathrm{NO}_{3}{ }^{-}-\mathrm{N}$ concentrations, but a positive correlation was observed between microbial $\mathrm{NO}_{3}{ }^{-}-\mathrm{N}$ reduction rates and suspended solid content. In Poyang Lake, denitrification rates ranging from $0.25 \pm 0.18$ to $0.63 \pm 0.24 \mu \mathrm{mol} \mathrm{N} \cdot \mathrm{L}^{-1}$, corresponding to ca. 3.5 to $8.8 \mathrm{mg} \mathrm{N}\left(\mathrm{m}^{3} \cdot \mathrm{d}\right)^{-1}$, suggested the occurrence of denitrifying processes on the surface of suspended solids [15]. Previous studies have reported a correlation between denitrification rates and $\mathrm{NO}_{3}{ }^{-}$content. In this study, $\mathrm{NO}_{3}{ }^{-}-\mathrm{N}$ reduction rates were negatively correlated with $\mathrm{DO}$ concentrations, similar to the findings of Wang (2015), who reported a significant correlation between $\mathrm{N}_{2} \mathrm{O}$ production rates and DO. Denitrification can be affected by suspended solids, whose surface can provide microscopic interstices characterized by anaerobic conditions for denitrification to occur. In addition, $\mathrm{NO}_{3}{ }^{-}-\mathrm{N}$ adsorbed on the surface of suspended solids can be removed from the water column through deposition. $\mathrm{NO}_{2}{ }^{-}-\mathrm{N}$ reduction rates showed a significant positive correlation with initial $\mathrm{NO}_{2}{ }^{-}$concentrations and a negative correlation with $\mathrm{DO}$. As the substrate for the second part of the nitrification process, $\mathrm{NO}_{2}{ }^{-}$concentrations can directly affect nitrification rates. $\mathrm{NO}_{2}{ }^{-}$concentration is generally the primary factor affecting nitrification rates under limiting $\mathrm{NO}_{2}{ }^{-}$levels, with other environmental factors becoming significant when $\mathrm{NO}_{2}{ }^{-}$is not limiting.

\subsection{DIN Reduce Processes}

In this study, the fraction of DIN reduction rates associated with non-microbial processes was higher than that accounted for by microbial activities, suggesting that adsorption and sedimentation had a stronger effect than biotransformation on DIN reduction rates. However, sedimentation of suspended matter is expected to be less prominent in a natural river setting than what we observed in our study. Because our experiment was conducted in a glass culture flask and no external water was supplied continuously, we may have overestimated the relative contribution of non-microbial processes on DIN reduce. Nevertheless, our results on the main DIN transformation processes and the overall effects of non-biological and microbial processes on spatio-temporal differences are realistic, because we ensured identical in-situ experimental conditions among seasons and sampling sites. Spring and summer DIN reduction rates in the absence of microbial activity varied greatly because of strong differences in flow velocity among sampling sites (Table 1), as indicated by the observed relationship between non-microbial DIN reduction rates, water velocity and $\mathrm{pH}$ (Table 3) [29]. Coupled nitrification-denitrification is the main biological process contributing to DIN reduce [30-32]. We found no correlation between DIN reduction rates and concentrations of different $\mathrm{N}$ forms, suggesting that $\mathrm{N}$ compounds were present in sufficient concentrations and did not represent a limiting factor [13]. We found a significant positive correlation between microbial DIN reduction rates and suspended solids, indicating that the presence of suspended solids can accelerate nitrification-denitrification processes and promote DIN reduce $[15,22,33]$.

We estimated that $\mathrm{N}$ reduce by microbial activities accounted for $7.9-61.2 \%$ of the DIN load (average: $29.7 \%$ ) and $0-6.4 \%$ of the $\mathrm{N}$ load (average: $2.2 \%$ ). Our results are consistent with previous studies, which estimated that the amount of $\mathrm{N}$ removed by denitrification accounted for $4.6 \%$ and $6.3 \%$ of the N load in the Mara River Basin and in Poyang Lake, respectively [15,34].

\section{Conclusions}

In natural conditions, $\mathrm{N}$ transformation and transport mechanisms mediated by biological and non-biological processes can reduce the $\mathrm{N}$ content in river water. In order to determine the differences in reduce processes and rate of different $\mathrm{N}$ forms and assessed the contribution of biological processes to dissolved inorganic $\mathrm{N}$ (DIN) reduce and the effects of different environmental factors on $\mathrm{N}$ reduce processes, we designed an experimental apparatus to conduct in-situ culture experiments in six rivers in the Taihu Lake Basin. We found that reduction rates of different $\mathrm{N}$ forms were higher in summer 
and autumn than spring and winter, with biological and non-biological processes playing a stronger role in summer and winter, respectively. Biological and non-biological DIN reduction rates differed spatially and temporally. Although non-biological processes played a major role in $\mathrm{N}$ reduce, biological processes are the main mechanism that can permanently remove $\mathrm{N}$ from the water column. Various factors affected the observed spatio-temporal differences in $\mathrm{N}$ reduction rates. The main influencing factors were the concentrations of different $\mathrm{N}$ forms and multiple environmental factors in spring, $\mathrm{N}$ concentrations, $\mathrm{DO}$ and $\mathrm{pH}$ in summer, $\mathrm{N}$ concentrations and water velocity in autumn and $\mathrm{N}$ concentrations in winter. Although our results may overestimate the effects of non-microbial processes in removing $\mathrm{N}$ forms due to the design characteristics of our experimental apparatus, the observed temporal and spatial patterns were not affected and can be considered realistic.

Author Contributions: writing-original draft preparation, J.G.; supervision, L.W. and C.Z.; investigation, J.G. and X.G.; Resource, G.Z. and J.D. and L.W.; Methodology, J.D.

Funding: This research was funded by the Major Science and Technology Program for Water Pollution Control and Treatment [No. 2017ZX07203002-02-01, 2017ZX07205-02] and was funded by the Natural Science Foundation of China [No. 41271213].

Acknowledgments: This research was supported by the Major Science and Technology Program for Water Pollution Control and Treatment (2017ZX07203002-02-01). In addition, this research was supported by the Natural Science Foundation of China (No. 41271213), and the China National Fund for Water Pollution Control and Management Project (No. 2017ZX07205-02). The authors are grateful to everybody who contributed to field surveys.

Conflicts of Interest: The authors declare that they have no conflict of interest.

\section{References}

1. Vitousek, P.M.; Aber, J.D.; Howarth, R.W.; Likens, G.E.; Matson, P.A.; Schindler, D.W.; Schlesinger, W.H.; Tilman, D.G. Technical report: Human alteration of the global Nitrogen cycle: Sources and consequences. Ecol. Appl. 1997, 7, 737-750. [CrossRef]

2. Galloway, J.N.; Dentener, F.J.; Capone, D.G.; Boyer, E.W.; Howarth, R.W.; Seitzinger, S.P.; Asner, G.P.; Cleveland, C.C.; Green, P.A.; Holland, E.A. Nitrogen Cycles: Past, Present, and Future; Royal Horticultural Society: London, UK, 2004; pp. 153-226.

3. Mulholland, P.J.; Helton, A.M.; Poole, G.C.; Hall, R.O.; Hamilton, S.K.; Peterson, B.J.; Tank, J.L.; Ashkenas, L.R.; Cooper, L.W.; Dahm, C.N. Stream denitrification across biomes and its response to anthropogenic nitrate loading. Nature 2008, 452, 202-205. [CrossRef] [PubMed]

4. Novotny, V.; Wang, X.; Englande, A.J.; Bedoya, D.; Promakasikorn, L.; Tirado, R. Comparative assessment of pollution by the use of industrial agricultural fertilizers in four rapidly developing Asian countries. Environ. Dev. Sustain. 2010, 12, 491-509. [CrossRef]

5. Seitzinger, S.P.; Styles, R.V.; Boyer, E.W.; Alexander, R.B.; Billen, G.; Howarth, R.W.; Mayer, B.; Breemen, N.V. Nitrogen retention in rivers: Model development and application to watersheds in the northeastern U.S.A. Biogeochemistry 2002, 57-58, 199-237. [CrossRef]

6. Singh, K.P.; Malik, A.; Sinha, S. Water quality assessment and apportionment of pollution sources of Gomti river (India) using multivariate statistical techniques-A case study. Anal. Chim. Acta 2005, 538, 355-374. [CrossRef]

7. Yang, S.Q.; Liu, P.W. Strategy of water pollution prevention in Taihu Lake and its effects analysis. J. Great Lakes Res. 2010, 36, 150-158. [CrossRef]

8. Qin, B.; Xu, P.; Wu, Q.; Luo, L.; Zhang, Y. Environmental issues of Lake Taihu, China. Hydrobiologia 2007, 581, 3-14. [CrossRef]

9. Yang, L.R.; Chen, L.D. River ecosystems and their self-purification capability: Research status and challenges. Acta Ecol. Sin. 2009, 29, 5066-5075.

10. Seitzinger, S.P. Denitrification in freshwater and coastal marine ecosystems: Ecological and geochemical significance. Limnol. Oceanogr. 1988, 33, 702-724. [CrossRef]

11. Zhang, B.; Du, Y.; Chen, Y.; Zhang, L.; Zhang, B.; Du, Y.; Chen, Y.; Zhang, L.; Zhang, B.; Du, Y. Denitrification in sediments of typical rivers in Taihu Basin. Acta Sci. Circumst. 2012, 32, 1866-1873. 
12. Bellinger, B.J.; Jicha, T.M.; Lehto, L.R.P.; Seifert-Monson, L.R.; Bolgrien, D.W.; Starry, M.A.; Angradi, T.R.; Pearson, M.S.; Elonen, C.; Hill, B.H. Sediment nitrification and denitrification in a Lake Superior estuary. J. Great Lakes Res. 2014, 40, 392-403. [CrossRef]

13. Wang, J.; Chen, N.; Yan, W.; Wang, B.; Yang, L. Effect of dissolved oxygen and nitrogen on emission of $\mathrm{N}_{2} \mathrm{O}$ from rivers in China. Atmos. Environ. 2015, 103, 347-356. [CrossRef]

14. Zhao, Y.; Xia, Y.; Ti, C.; Shan, J.; Li, B.; Xia, L.; Yan, X. Nitrogen removal capacity of the river network in a high nitrogen loading region. Environ. Sci. Technol. 2015, 49, 1427-1435. [CrossRef] [PubMed]

15. Yao, X.; Zhang, L.; Zhang, Y.; Xu, H.; Jiang, X. Denitrification occurring on suspended sediment in a large, shallow, subtropical lake (Poyang Lake, China). Environ. Pollut. 2016, 219, 501-511. [CrossRef] [PubMed]

16. Xia, X.H.; Yang, Z.F.; Huang, G.H.; Zhang, X.Q.; Yu, H.; Rong, X. Nitrification in natural waters with high suspended-solid content-A study for the Yellow River. Chemosphere 2004, 57, 1017-1029. [CrossRef] [PubMed]

17. Zuo, R.; Jin, S.; Chen, M.; Guan, X.; Wang, J.; Zhai, Y.; Teng, Y.; Guo, X. In-situ study of migration and transformation of nitrogen in groundwater based on continuous observations at a contaminated desert site. J. Contam. Hydrol. 2018, 211, 39-48. [CrossRef] [PubMed]

18. Kowalchuk, G.A.; Stephen, J.R. Ammonia-oxidizing bacteria: A model for molecular microbial ecology. Annu. Rev. Microbiol. 2001, 55, 485-529. [CrossRef] [PubMed]

19. Zumft, W.G. Cell biology and molecular basis of denitrification. Microbiol. Mol. Biol. Rev. 1997, 61, 533-616. [PubMed]

20. Francis, C.A.; Beman, J.M.; Kuypers, M.M.M. New processes and players in the nitrogen cycle: The microbial ecology of anaerobic and archaeal ammonia oxidation. ISME J. 2007, 1, 19-27. [CrossRef] [PubMed]

21. Kim, H.; Bae, H.S.; Reddy, K.R.; Ogram, A. Distributions, abundances and activities of microbes associated with the nitrogen cycle in riparian and stream sediments of a river tributary. Water Res. 2016, 106, 51-61. [CrossRef] [PubMed]

22. Xia, X.; Liu, T.; Yang, Z.; Michalski, G.; Liu, S.; Jia, Z.; Zhang, S. Enhanced nitrogen loss from rivers through coupled nitrification-denitrification caused by suspended sediment. Sci. Total Environ. 2016, 579, 47-59. [CrossRef] [PubMed]

23. Huang, J.; Duan, Y.H.; Ming-Gang, X.U.; Zhai, L.M.; Zhang, X.B.; Wang, B.R.; Zhang, Y.Z.; Gao, S.D.; Sun, N. Nitrogen mobility, ammonia volatilization, and estimated leaching loss from long-term manure incorporation in red soil. J. Integr. Agric. 2017, 16, 2082-2092. [CrossRef]

24. Guo, C.; Guohua, Y.U. Adsorption properties of sediment to pollutants of contaminated river water. Ecol. Environ. 2006, 15, 1151-1155.

25. Chen, G.Y. Effects of Different NH_3-N Concentrations on the nitrification process in waters and sediment from Zhushan Bay, Taihu Lake. J. Hydroecol. 2012, 2, 010.

26. Pauer, J.J.; Auer, M.T. Nitrification in the water column and sediment of a hypereutrophic lake and adjoining river system. Water Res. 2000, 34, 1247-1254. [CrossRef]

27. Butturini, A.; Battin, T.J.; Sabater, F. Nitrification in stream sediment biofilms: The role of ammonium concentration and DOC quality. Water Res. 2000, 34, 629-639. [CrossRef]

28. Jinxiu, L.I.; Liao, W. The effect of water flow on the biodegradation of organic pollutant. Res. Environ. Sci. 2002, 15, 45-48.

29. Xue-Zhong, Y.U.; Zhong, D.Y.; Jin-Xiu, L.I.; Liao, W.G. Review of studies on sediment in water environment. J. Sediment Res. 2004, 6, 75-81.

30. Jenkins, M.C.; Kemp, W.M. The coupling of nitrification and denitrification in two estuarine sediments 1, 2 . Limnol. Oceanogr. 1984, 29, 609-619. [CrossRef]

31. Codispoti, L.A.; Christensen, J.P. Nitrification, denitrification and nitrous oxide cycling in the eastern tropical South Pacific ocean. Mar. Chem. 1985, 16, 277-300. [CrossRef]

32. Carini, S.A.; Mccarthy, M.J.; Gardner, W.S. An isotope dilution method to measure nitrification rates in the northern Gulf of Mexico and other eutrophic waters. Cont. Shelf Res. 2010, 30, 1795-1801. [CrossRef] 
33. Liu, T.; Xia, X.; Liu, S.; Mou, X.; Qiu, Y. Acceleration of denitrification in turbid rivers due to denitrification occurring on suspended sediment in oxic waters. Environ. Sci. Technol. 2013, 47, 4053-4061. [CrossRef] [PubMed]

34. Mayo, A.W.; Muraza, M.; Norbert, J. Modelling nitrogen transformation and removal in Mara river basin wetlands upstream of lake Victoria. Phys. Chem. Earth Parts A/B/C 2018, 105, 136-146. [CrossRef]

(C) 2018 by the authors. Licensee MDPI, Basel, Switzerland. This article is an open access article distributed under the terms and conditions of the Creative Commons Attribution (CC BY) license (http:/ / creativecommons.org/licenses/by/4.0/). 